\title{
Caution with deviant neighbours: Explaining degrees of non-tariff protectionism with spatial analysis
}

\author{
Aleksey Domanov \\ Institute for International Studies, Center for Spatial Analysis in \\ International Relations, Jean Monnet Chair of Integration Processes, \\ MGIMO University (Moscow State Institute of International \\ Relations), Russia \\ domanov.aleksey@gmail.com
}

ORCID 0000-0002-6253-2067

Igor Okunev

Institute for International Studies, Center for Spatial Analysis in

International Relations,

MGIMO University (Moscow State Institute of International

Relations), Russia

iokuner@mgimo.ru

ORCID 0000-0003-3292-9829

Abstract. This paper deals with protectionist barriers as a risk mitigation method to avoid contaminated or unreliable products. A spatial analysis of introduced defensive measures (namely, technical barriers) has been carried out to determine the characteristics of neighbouring societies that stimulate protectionist reactions from states. This willingness to establish technical barriers against goods was attributed to neighbouring citizens' desire to violate accepted rules and deviate from common standards (including manufacturing). Countries surrounded by nonconformist trade partners considered opening their borders to be hazardous. The abovementioned results were observed in countries with vulnerabilities of different kinds (low GDP PPP per capita, Competitiveness Index, Globalization Index and high state fragility). Contiguity effects have been estimated using unorthodox quantitative methods: by computing Bivariate Moran's I coefficient and evaluating local indicators of spatial association (LISA methodology). The chosen dependent and independent variables were observed for the period between 2005 and 2019.

Keywords: protectionism, human values, Autonomy Index of C. Welzel, spatial analysis, developing countries. 
JEL Classification: C31, C54, F13, Z13

\section{INTRODUCTION}

What if factory workers, sick with a long-living disease transmitted through physical contact with objects, ignored employer-prescribed quarantine rules, so they eventually came to their workplace and sent contaminated manufactured goods abroad? These dangerous products could be prohibited from crossing national border by introducing custom restrictions. In this case, non-tariff barriers seem to be more selective than tariff ones: by using, for instance, sanitary norms or technical standards instead of prohibitively high levies, importing countries could halt only the exchange of dangerous goods rather than the entire transnational trade flow in the corresponding industry branch.

These protectionist barriers could be regarded in this case as a risk mitigation method applied to limit exposure to some hazards abroad (e.g., dangerous way of manufacturing). Yet, these measures are not introduced universally. Although many governments have shifted from globalist to protectionist foreign policies in recent years, numerous states still remain committed to international openness.

The reasons for this discrepancy deserve scholarly attention, as the continuation of another global trend of the early $21^{\text {st }}$ century - growing regional integration groupings - depends on the readiness of neighbouring countries to open their borders. In particular, the following question is worth touching upon: Why do some countries introduce protectionist barriers?

Protectionist barriers have traditionally been explained through global variables or phenomena localised inside the country pursuing the given policy. In this regard, a neighbourhood-level analysis would give an unconventional point of view on many of the issues explored (and more so on issues that have not been given much attention). Besides, having adopted a risk governance perspective on protectionism, we should probably account for contiguity effects: as proximity to risk sources was proven to significantly affect risk assessment processes and results (Poortinga et al., 2008), protectionist reactions to threats could also differ in intensity depending on distance to these hazards. The methodological approach used in this study allows us to record neighbouring effects.

Hence it would be more productive to reduce the research question posed above to the following: What characteristics of neighbouring societies stimulate protectionist reactions? To address this issue, we need to expand on the described causal chain from the appearance of a hazard to the introduction of barriers. The present paper is thus structured as follows: the first two sections are dedicated to theory, revising the relevant literature and describing the conceptual framework used in the empirical part of the paper; this is followed by a description of the variables to be used; we then go on to outline the spatial analysis methodology; finally, we present and discuss the results of the quantitative study for 2005-2019.

\section{LITERATURE REVIEW: INTERDISCIPLINARY PERSPECTIVES ON TRADE BARRIERS}

International relations (IR) scholars have used various paradigms to analyse economic foreign policy instruments in recent decades. For neorealists, these tools appear to be ancillary to military ones in attempts to maintain the balance of power (Waltz, 2008). In this respect, trade tariffs could be regarded as a way to replenish the national security budget. Non-tariff barriers are also considered useful for national interests: in particular, to ensure sovereignty, especially after its economic dimension started to gain importance with the spread of globalization (Krasner, 1999). 
Trade policy instruments fall, among other things, within the scope of the 'offensive realist' interpretation of state behaviour (Mearsheimer, 2001). If a government is seen to be targeting more than simple survival - at altering the balance of power - then it uses different tools (including economic) to strengthen its influence over its neighbours on its path towards hegemony.

Countries are typically described by economists working in various fields as following an 'offensive neorealist' logic. International economist J. Culbertson (1986) reviewed policies to avoid a trade balance deficit; political economists David Calleo and Benjamin Rowland (1973, p. 140) analysed how mercantilist goals could incentivize states to move away from maintaining the status quo towards the pursuit of global economic leadership; geoeconomist Pascal Lorot (1999) investigated commercial strategies and economic policies that allow national companies to achieve leading positions in the world; and E. Luttwak (1990) established a direct link between national security and economic objectives - for example, disregarding the costs of economic agents beyond state borders and improving the revenue of domestic companies.

Neoliberal IR scholars have been paying closer attention to domestic players that affect foreign policy. For instance, commercial liberalism has focused on aggregating the preferences and cost-benefit calculations of internal economic actors (including citizens - Moravcsik, 1997, p. 518) regarding their international competitors and partners. As neoliberal analysis accounts for interest groups with opposing claims, this approach appears to be suitable for explaining policies that both restrict and encourage international trade. The so-called 'domestic distributional conflict' between stakeholders emphasized by Andrew Moravcsik (1997, p. 529), has been found to cause resistance to countries opening their markets. Preference convergence between those private stakeholders and decision-makers (Mansfield, Busch, 1995) on the one hand and national institutions employed to aggregate these demands on the other (Rickard, 2012) were found to make the introduction of non-tariff barriers more likely.

The neoliberal emphasis on international normative harmonization explains the focus of policy-makers on non-tariff barriers. As international organizations like the WTO tend to promote the gradual concerted reduction of trade tariffs, companies and governments need to increase legitimacy of their remaining protectionist measures - non-tariff obstacles - by resorting to generally accepted procedures within the same institutions. For instance, the 'precautionary principle' under the Agreement on the Application of Sanitary and Phytosanitary Measures, which allows measures to protect local competitors to be taken (when a government considers that sufficient scientific evidence does not exist to permit a final decision on the safety of a product or process), has been explored in international law (Cheyne, 2007; Huei-Chih, 2007) and economics (Post, 2006; including the behavioural aspects: Epps, 2008; Goldstein, Carruth, 2004) as a WTOjustified pretext to adjust international standards and reinforce some trade barriers.

Constructivists moved this neoliberal recognition of the intrastate context of foreign economic policy forward by emphasizing the influence that citizens have on governmental decision-making. Individuals are considered capable of shaping norms and common principles in accordance with their identities, and these preferences could be aggregated into a national policy. From the economic point of view market rules are supposed to be constructed intersubjectively during ongoing bargains (Abdelal et al., 2010; Hall, 2006), and formal negotiations between representatives of different social groups are not believed to provide sufficient explanation for the flexibility of norms: for instance, John Hobson and Leonard Seabrooke (2007) proposed looking at everyday activities that change economic structures.

In addition to shifts in power between groups with opposing preferences, these transformations could arise from changes in the economic situation. External factors could stimulate an individual to reconsider his or her beliefs and role on the market while following the same set of rules (containing this specific division of roles - embracing the old and the new) to achieve one's goals (Onuf, 1997, p. 17) or choosing to violate accepted norms and formulate a new strategy in order to gain benefit or reduce a counterpart's profit (Onuf, 1997, p.15). 
Some economists unrelated to constructivist IR paradigm agree that consumer choices should be taken into account during international trade research. Resentment towards some products has been analysed at the individual level (Friedman, 2010), within social movements (Balsiger, 2010) and on a national scale (Rinkinen et al., 2020). Consumer requests have been shown to exert significant pressure on trade policymaking, both domestically (Meunier, 2005) and globally (Perdikis et al., 2001). Post-structural international political economists agree with constructivist IR scholars, emphasizing the difficulties in transactional interpretation, the efforts of agents to construct and assign a meaning to it, and justifications for rejecting certain rules and products (Wullweber, 2018; De Goede, 2006).

When determining the criteria for discouraging the import of a particular product, researchers do not get bogged down with materialist self-interest variables (Melgar et al., 2013) such as wage increases after proposed bans on foreign imports that would push down the prices of locally produced goods (Auer, Fischer, 2010; Fajgelbaum, Khandelwal, 2016; Hays et al., 2005; Mayda, Rodrik, 2005; Scheve, Slaughter, 2001). Economic sociology regards consumer actions in relation to their social context (Granovetter, 1985, p. 487), while the substantivist approach to economic anthropology underlines variability in reaction to similar conditions in different societies (Gudeman, 1986, p. 38; Prattis, 1982). The most extensively analysed contextual components of a product's subjective value appear to be those that are related to quality judgements and opinions about its community of origin.

Economist Jens Beckert (2020) believes quality to be an intersubjective construction: consumers often come to a shared understanding of the characteristics of a product. Sociologists Thomas Luckmann and Peter Berger (1966) attribute the distinction people make between nutritional goods to socialization. Social anthropologist Mary Douglas (1966, pp. 41-57) found that dietary traditions were based on specific interpretations of social boundaries and institutions: a good could be rejected because of a trait deemed unacceptable in one community, but regarded as a necessary quality in another. Sociologists Michel Callon, Cécile Méadel and Vololona Rabeharisoa point out that differences in categorization methods and notions describing objects affect how we evaluate the quality of a product (Callon et al., 2002).

According to sociologist Pierre Bourdieu (1984, p. 56), resentment towards goods could stem from the prevalence of aesthetics and standards that legitimize disgust and intolerance to 'abnormal' tastes. Economic anthropologist Elizabeth Shove (2003) also believes that normality criteria adopted in communities shapes consumption patterns. The objectionable status of objects and practices for communities that share the same normality interpretation ('orders of worth' constructed in line with accepted norms and context-based 'conventions' - Boltanski, Thévenot, 1991), could result in the rejection of products on the grounds of presumably low quality (Storper, Salais, 1997).

A government could place restrictions on some goods to underline their 'abnormality,' even if their failure to meet constructed standards is minimal and tolerated by consumers. Anthropologist Julia Kristeva (1982) noticed that casting people and objects off reinforces group solidarity: from her point of view, this process is often instrumentalised to preserve a community's identity by creating normative borders. A similar function was assigned to selection by sociologist Niklas Luhmann (1995): according to his theory, any community reproduces itself in 'autopoietic' process, which requires an ongoing redrawing of borders with surrounding coevolving social systems and the environment. These differentiation codes are maintained as relatively stable normative orders, because citizens make repeated references to previously approved or rejected elements, therefore preserving consistency of the community.

In the same vein, trade and manufacturing practices in the product's place of origin can be divided into widely accepted and 'abnormal,' which should be discouraged and protected against (for instance, by requiring an additional filter in the form of costly certification). The lack of consistent transnational oversight over some workers and production sites abroad could lead consumers to expect negative externalities from these firms and consequently call for strict customs control to be introduced in the form 
of non-tariff barriers. It is worth noting that people (for example, factory workers who do not 'fit' social standards) can be rejected and seen as 'disgusting' in much the same way as things, when they are considered dangerous because they either pollute objects within their reach (Anderson, 1995) or refuse to follow accepted economic rules (Tyler, 2013). This could lead to their becoming stigmatized (Goffman, 1963) and consequently marginalized as 'dirty' (Valentine, 2008; Moore, 2009).

Academic studies of resentment reveal two phenomena: this individual stigmatization and marginalization often degenerate into attitudes towards communities and affect economic relations. Economists stress their findings on ethnocentrism (Guisinger, 2017; Mansfield, Mutz, 2009) and religious motivation (Guiso et al., 2003) in choosing trade partners.

Outgroups relevant for this article are distinguished by location criteria, although the aforementioned ethnic and religious divisions could coincide with administrative borders. Loïc Wacquant has analysed the stigmatization of these localized communities (2010). According to him, the term 'territorial stigma' might be correctly applied to a group if people who are different from the observer are discredited, and if their pejorative nomination - described by Bourdieu's symbolic power theory (Bourdieu and Thompson, 1991, pp. 220-221) - carries certain consequences. For ingroups, such stigmatized geographical entities are found to stimulate protective reactions. In particular, policy analysts would be interested in two of eight strategies typically aimed at helping society coping with 'territorial stigma' (Wacquant et al., 2014, p. 1276): distancing and the more active collective defence of one's borders.

The emotional (Anderson, Smith, 2002; Bondi et al., 2005), fear- (Sparke, 2007; Bleiker, Leet, 2006) and consumption-based (Crewe, 2011) aspects of the spatial distribution of more general economic resentment have also been explored. These scholars focus on people's opinions on territorial entities to which they are frequently exposed - neighbouring countries.

\section{The risk assessment approach: Trade policies as risk mitigation strategies, threat sensitivity}

In order to find a solution to this problem, it may be useful to take the cognitive phenomena that intervene in the relationship between these hazards and reactions to them in addition to simply analysing sources of risks. This approach relies on the accepted view of risk situations: that they involve an actor perceiving and assessing a risk coming from a source (Scholz et al., 2012). In this sense, risks are usually socially constructed and their characteristics are closely intertwined with information available to actors (Douglas, 1992; Flanquart, 2012). Hence, any explanation of how and why states try to counter a given hazard should require researchers to look at how information about threats is treated.

Information treatment analysis seems to be necessary especially when dealing with political decisions: the choice to introduce certain measures could be regarded as a result of opinion construction. As the models of political systems put forth by Easton (1965) and Deutsch (1988), as well as the constructivist paradigm (founded in international relations by Wendt, 1992) suggest, policy analysis should take due account of how information is treated by decision-makers: their beliefs about an object under their regulation and its surroundings, and how the data processing behind the resulting opinions determines their policies. In cases of counter-hazard measures, this means accounting for risk perception.

Likewise, beliefs and information treatment have been shown to be significant factors in foreign policy decisions. For example, Holsti and Rathbun attribute the variability of foreign policy (among other factors) to changes in the images and values of decision-makers (Holsti, 2004; Rathbun, 2011).

Of particular relevance to our current study are actors' opinions about the environment rather than about their own resources. Looking at risk situations in general, Beck (2009) emphasized that 'risk defines a social relation.' From the political point of view, analysing actors' opinions about external phenomena 
corresponds to the well-established tradition of examining one's enemies. The framework elaborated by Buzan and Wrver (2003) seems to be among the most useful here. The more general observations of Holsti (2004), who suggested accounting for negative expectations about external actors, and Hill and Wallace (Hill and Wallace, 1996, p. 8), who asserted the impossibility of a foreign policy without some enemy image, are also applicable to our study.

We could thus suppose that risk assessment leading to protectionist measures includes opinions about imported products and social relations in the buyer-manufacturer relationship (about the workers who made those goods). As custom barriers are categorized by countries of origin of products, it may be fair to assume that risk assessments underlying decisions to introduce these barriers also differ from one country to another (that consumers of imported goods give their evaluations to various populations limited by the boundaries of distinct states).

As protectionist policies are based on perceptions of a source of risk, it would be worth analysing the following elements of information treatment process: who can process data about what phenomena to derive protectionist conclusions. It would be appropriate to identify some risk sources first, and then proceed to look for customers who are likely to be irritated by these particular characteristics and consequently react in a defensive manner.

Consumers of imported goods run the risk of not getting the same utility from these products that they are used to (when they bought these products). Therefore, importing states could attempt to distance themselves and defend their national market from things with unpredictable characteristics and utility.

This lack of utility could originate from the poor quality of the products: for example, they may not be as reliable as expected, or they could be dangerous to the consumer's health. In turn, goods might not be sufficiently standardized, because foreign workers and entrepreneurs either cannot keep up with high standards (do not have the necessary resources - for instance, workers in the country of origin may not be qualified to manufacture the product in a predictable manner; or the quality of the raw materials extracted in this country are nor consistent), or do not want to stick to these rules of production (willingly violate them).

Policy-makers aiming to protect their national market from non-standardized imports are faced with the challenge of trying to predict whether or not foreign-made goods will deviate from desired standards (i.e. if the inconsistent quality observed in goods that have already cleared customs will continue). One of the ways to accomplish this task is to estimate the extent to which citizens in neighbouring countries are ready to manufacture goods in a standardized manner: if they intend to break the rules of production today, then they are likely to do the same in the long term.

States can make assumptions about the work ethic of overseas employees by assessing their attitudes towards compliance with accepted norms. Hence, what could be deemed risky by societies introducing protectionist barriers is a form of social deviance or non-conformity, where conformity is understood as respect for legitimate or approved means of achieving goals (Merton, 1968).

Societies that frequently violate the standards of conduct (in particular, during the manufacturing process) are expected to produce goods that deviate from common standards. Consequently, importing societies try to not consume those products that could deliver insufficient (and in that sense unexpected) utility. And the opposite is also true: societies that tend to follow the rules and conform to prescribed procedures are expected to produce standardized goods, which could be imported without any risk of losing consumption utility.

Hazards of this nature are most likely to trigger a protectionist reaction (having shaped a negative opinion) among people who experience material vulnerability. The risk of products losing their utility described above is particularly sensitive for them, because from a risk perspective these people have the lowest risk tolerance. Indeed, judging by the studies of risk perception carried out by Dosman and his colleagues (Dosman et al., 2001), financial health is one of the strongest predictors of risk tolerance level. 
People experiencing financial difficulties may be especially cautious when looking at the unpredictability of citizens in neighbouring countries, because they are more sensitive to the lack of utility after buying non-standardized goods than wealthy people. In extreme cases, people in financial need may suffer unbearable damage if they purchase an appliance that turns out to be unreliable: they do not have the money to replace the product with something more standardized and trustworthy.

As for consumers who are not as limited financially, they can afford to replace products with short shelf-lives. Moreover, they are less likely to buy cheap products in the first place, as they have the money to buy goods that are known for their reliability.

Consequently, if governments of poor countries try to protect the health and way of life of their impoverished citizens, they could intentionally deprive them of this choice by preventing unwelcome products from entering national markets by introducing additional import barriers.

Following the same logic of expected damage, other variables may also have a moderating effect on protectionist policy, because the perceived impact of harmful events is predicted by various types of social vulnerability (Khunwishit and McEntire, 2012). Supposedly, people living in fragile states (i.e. experiencing hardships that are not exclusively economic in nature) may also need government protection in the form of custom barriers.

The socioeconomic success of a state could also stimulate its open trade policy in another way. A government may be more certain that citizens will not buy unreliable goods if their domestic economy produces globally competitive import substitutes: in this case, people know that nationally produced goods are of high quality, and the competitiveness of the country's industry suggests a price-quality ration that is comparable to that of foreign goods.

Bearing in mind the abovementioned theoretical background, one could hypothesize that 'vulnerable' nation states express a different (protectionist) reaction to non-conformist citizens of contiguous countries than 'resilient' states.

\section{VARIABLES AND METHODOLOGY}

At first sight, the most suitable indicator for the dependent variable is the strength of tariff trade barriers: this subject is well-researched, so a specially constructed measurement scale (Riezman, Whalley \& Zhang, 2011) can be applied. However, this choice may lead to biased results due to the low values of this indicator in EU countries. Although the member states of this integration group have agreed to maintain minimal customs duties (in line with the free trade approach), the citizens of many EU countries still have protectionist preferences (as suggested by recent rise in the popularity of nationalist parties). Moreover, customs duties may rise due to reasons that are not related to public opinion: for example, in order to cope with a budget deficit.

As for another type of barriers, non-tariff ones, they seem to allow for less biased research. Given that the present study is concerned with mass production standards, technical standards (as a subcategory of barriers) should be chosen for further analysis.

The number of restrictive measures arising from technical standards is calculated by the WTO (I-TIP Goods, 2020), with the latest publication available for our research appearing in 2019.

The independent variable should reflect the abovementioned object-specific characteristics of the risk (contiguous countries), whereas moderating variables should capture various features of actors experiencing protectionist moods. The feature corresponding to the independent variable - attachment to conformity, willingness to follow rules - seems to be reflected in the Autonomy Index constructed by C. Welzel on the basis of World Values Survey (WVS) responses (above all, relying on those concerning disobedience and non-conformity). 
The index is explained in more detail in (Welzel, 2013, pp. 66-69). According to this methodological approach, the Autonomy Index can indeed be used to assess whether citizens in neighbouring countries appreciate acting in accordance with standard procedures (for example, in the manufacturing of goods).

The latest two waves of the WVS (conducted by the WVS Association and freely available at the time of our analysis in the form interviews conducted in 2005-2014, see: Inglehart et al., 2014) were used for this study. We chose two waves in order to ensure that the information available was wide in scope and novel. Our database brings together the responses of people living in 77 countries. The distribution of values is illustrated in Fig. 7 of the Appendix.

We had to select moderating variables that would allow us to distinguish between vulnerable and resilient states. In particular, the following characteristics are suitable as country-level risk tolerance factors (sensitivity to cross-border threats), which could modify the relationship between the selected dependent and independent variables:

- GDP PPP per capita in international dollars (the data for 2018 was taken from the IMF website: World Economic Outlook Database, 2019)

- Competitiveness Index (evaluated by the World Economic Forum for 2017-2018: Global Competitiveness Index, 2019)

- KOF Globalisation Index (estimates carried out by the Swiss Economic Institute for 2017: KOF Globalisation Index, 2018)

- Fragile States Index (assessed by the Fund for Peace for 2017: Country Dashboard, 2018).

Having included these variables in our database, we were able to focus on threat sensitivity in countries with low GDP PPP per capita, high fragility and low competitiveness scores.

Descriptive statistical indicators for these variables are provided in the Appendix.

The scope of this study was limited to 77 countries, with all continents represented. Although indicators of moderating variables are available for almost every country, this paper only covers entities where all three blocks of variables are present. Hence, our sample was not limited to WTO countries (i.e. those where the dependent variable can be measured), extending further to the WVS sample (in order to analyse Autonomy Index values).

As this opinion poll costs a lot of money to conduct the waves used in our study cover 77 countries from across the globe. Consequently, this 'lowest common denominator' of variable types means that we selected independent and moderating variable values for these countries only.

While selecting a quantitative method for this study, we departed from the need to analyse relations between neighbouring entities. We found that bivariate spatial autocorrelation analysis is one of the most productive methods when it comes to accounting for any spatially determined entity, specifically estimating Moran's I (in this case with different independent and dependent variables - Bivariate Moran's I).

The index is calculated using the formula:

$$
M=\frac{N}{W} \frac{\sum_{i} \sum_{j} w_{i j}\left(x_{i}-\dot{x}\right)\left(x_{j}-\dot{x}\right)}{\sum_{i}\left(x_{i}-\dot{x}\right)}
$$

where $i$ and $j$ are units, $x_{i}$ and $x_{j}$ are values in $i$ and $j$ units, $x$ is a sample mean on all units, $w_{i j}$ are all spatial relations between the $i^{\text {th }}$ and $j^{\text {th }}$ units, $N$ is the quantity of units, and $W$ the sum of spatial weights (Cliff, Keith, 1973).

Furthermore, we used the Local Indicators of Spatial Association (LISA) method to evaluate spatial clusters, that is, to identify regions in the world with a statistically high dependence on neighbouring countries. The following formula was used:

$$
L=\frac{N}{\sum_{j} \sum_{j} w_{i j}} \frac{\sum_{i} \sum_{j} w_{i j}\left(z_{i}-\dot{z}\right)\left(z_{j}-\dot{z}\right)}{\sum_{i}\left(z_{i}-z^{2}\right)^{2}}
$$


where $N$ is the number of cells/partitions, $z_{i}$ is the calculated indicator for cell $i, w_{i j}$ is an estimate of spatial weights reflecting whether $i$ and $j$ are neighbours, such that if they are not, it is equal to zero, and if they are, it is equal to $\frac{1}{\left|\delta_{i}\right|}$, where $\left|\delta_{i}\right|$ is the number of neighboring cells $i$ (Anselin, 1995).

The local indications of spatial association were mapped for countries with a p-value of less than 0.05 . The given method revealed four types of local clusters: high-high is a cluster of spatial autocorrelation of high values in neighbouring countries, low-low is a cluster of spatial autocorrelation of low values in neighbouring countries, high-low are items of high value appearing in a neighbourhood cluster of low values, low-high are items of low value appearing in the neighbourhood cluster of high values.

A preliminary step for this methodology is overlaying the values of the variables onto a world map with the help of QGIS software. For this purpose, the data extracted from the abovementioned primary sources has been merged with a shapefile (World Borders Dataset, 2019), in which space is divided into real countries, so the resulting borders and neighbour links are correct.

These links between neighbour countries are impossible to account for without a contiguity matrix (which topologically operationalizes the principle of contiguity on this specific map - what territorial entities affect phenomena in a specific country). As rook and queen contiguity was considered inapplicable for our research purposes (as it regards island nations as having no neighbours), the spatial autocorrelation was calculated using $k$-nearest neighbours method. In this case, neighbours are defined as the first $k$ entities within a gradually enlarging circle around a country's centroid (Anselin, 2018; Dasarathy, 1991; Chen, 2012).

A contiguity matrix with $k=8$ was chosen in GeoDa software, because this number results in considerable correspondence to the socially conventional network of relations between countries. This averaged number of neighbours has been (e.g., in Okunev et al., 2020) instrumental in dealing with heterogeneity between countries.

\section{EMPIRICAL RESULTS AND DISCUSSION}

\section{Results}

Our spatial analysis revealed that the number of certain non-tariff barriers (namely, technical standards) in sub-samples of 'vulnerable' nation states (with GDP PPP per capita lower than 15,000 international dollars, a Competitiveness Index value lower than 60, Globalisation Index scores lower than 70 and Fragile States Index over 75) and 'resilient' states (with the values of the respective moderating variables over 15,000 international dollars, over 60 and lower than 75) is inversely dependent on the degree of non-conformity of the citizens of contiguous countries. Indeed, the readiness of people in neighbouring countries to deviate from common standards (including those for manufacturing products) gives rise to protectionist sentiments in 'vulnerable' states, but this link is not observed in 'resilient' states.

For the overall sample, Bivariate Moran's I between technical standards number and non-conformity among neighbouring citizens is positive (0.276) and significant (pseudo p-value for 999 permutations randomization was 0.001 and $z$-value was 5.2486, which is admissible in line with approaches adopted by Anselin, 2019; De Castro and Burton, 2006), as shown in Figs. 1, 2, 3 and 4. Meanwhile, this statistical coefficient for nation states with:

1) GDP PPP per capita lower than 15,000 international dollars is 0.331, as illustrated in Fig. 1 (right: scatter plot for the general sample; left: scatter plot for the low GDP PPP per capita subsample); 


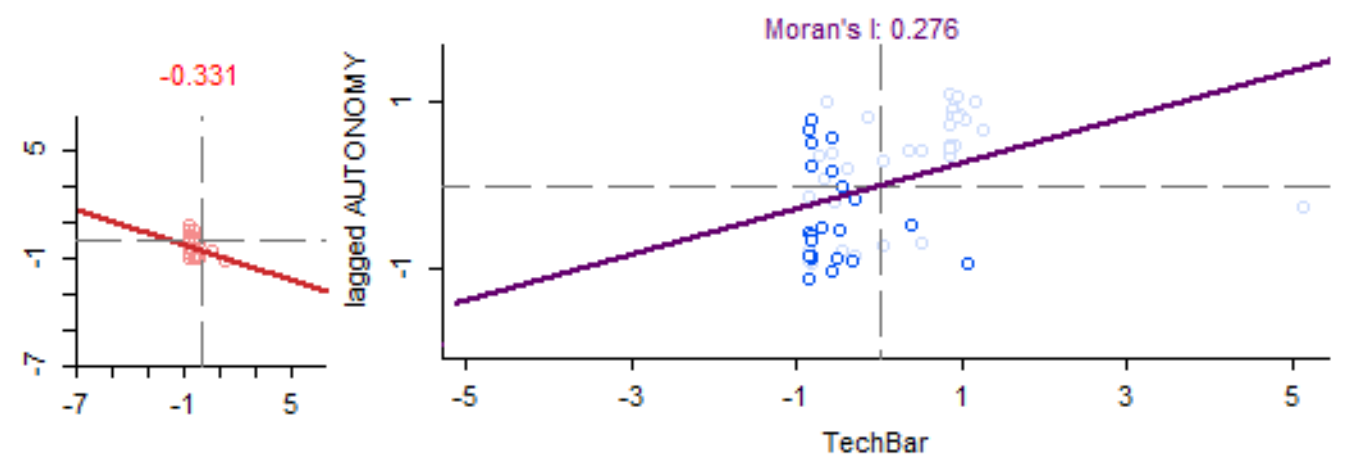

Figure 1. Scatter plot of the relationship between the autonomy index and the number of technical trade barriers

(among countries with low GDP PPP per capita and in the whole sample)

2) -0.186 for countries with a Competitiveness Index value lower than 60, as illustrated in Fig. 2 (right: scatter plot for the general sample; left: scatter plot for the least competitive subsample);

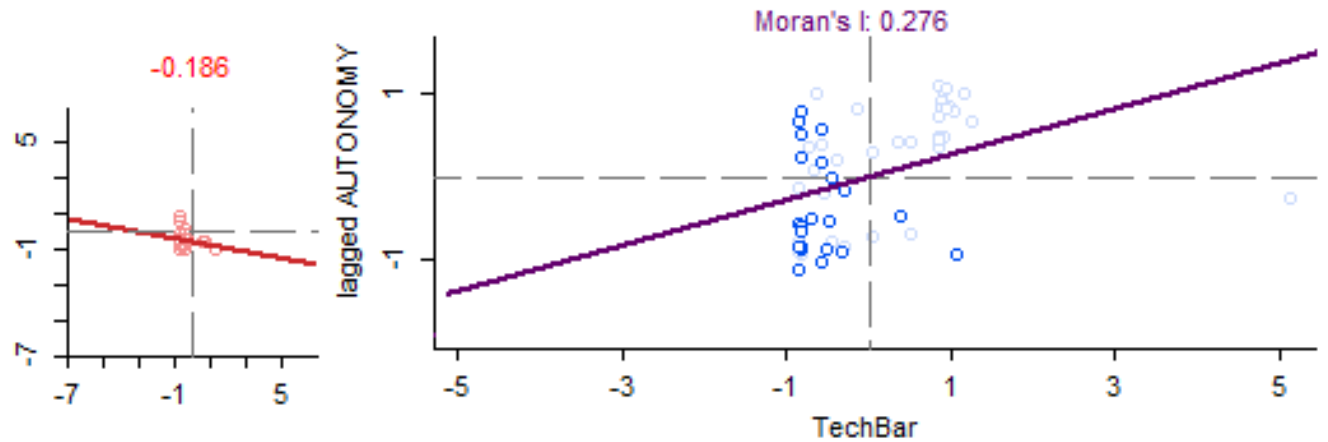

Figure 2. Scatter plot of the relationship between the autonomy index and the number of technical trade barriers

(among countries with low Global Competitiveness Index scores and in the whole sample)

3) -0.218 for states with Globalization Index scores lower than 70, as illustrated in Fig. 3 (right: scatter plot for the general sample; left: scatter plot for the poorly globalised subsample); and

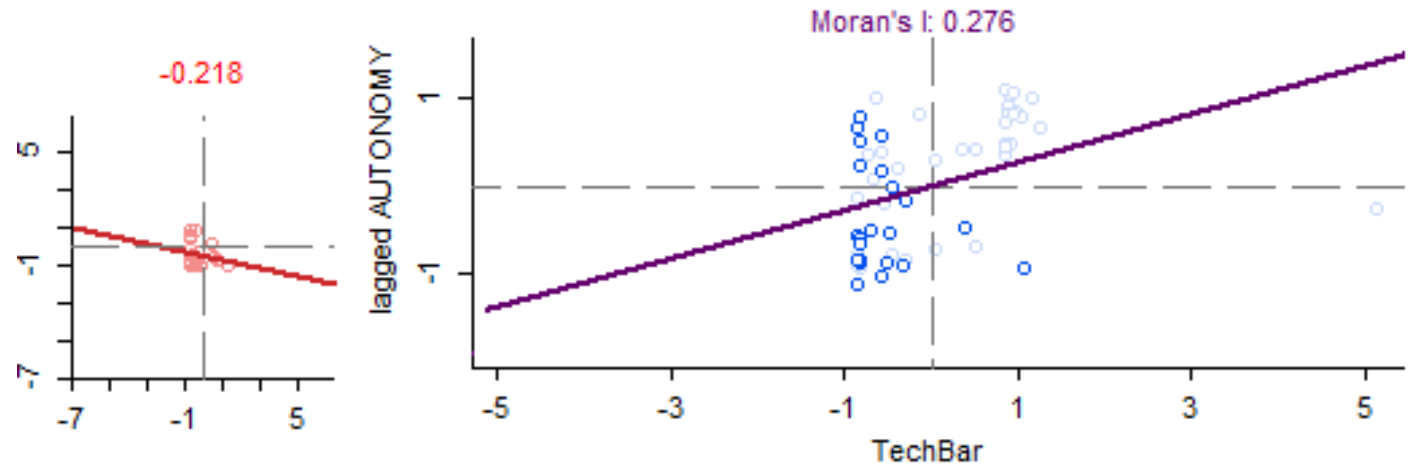

Figure 3. Scatter plot of the relationship between autonomy index and the number of technical trade barriers

(among countries with low KOF Globalisation Index scores and in the whole sample) 
4) -0.335 for countries with Fragile States Index over 75, as illustrated in Fig. 4 (right: scatter plot for the general sample; left: scatter plot for the relatively fragile subsample).

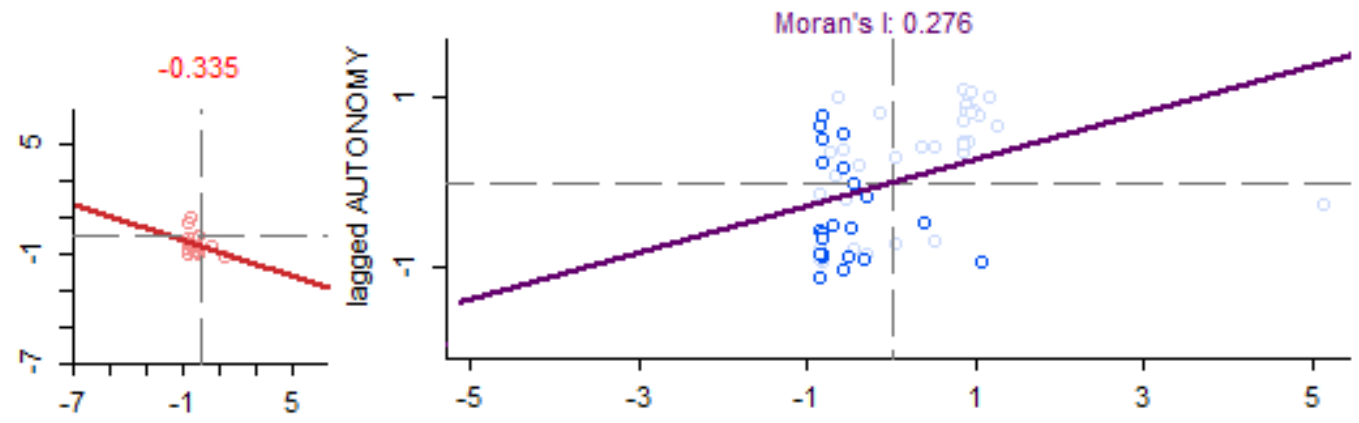

Figure 4. Scatter plot of the relationship between autonomy index and the number of technical trade barriers

(among countries with high Fragile States Index scores and in the whole sample)

These results could provide a basis for the hypothesis advanced above. This discrepancy is likely to be attributed to the circumstances laid out in the theoretical section of our study.

The calculated LISA values (mapped out in Fig. 5) supported these findings by demonstrating contrasting reactions to neighbouring societies by states in the same regions. Several countries stand out in terms of the number of technical barriers number to the level of non-conformity in neighbouring societies: Mexico and Ecuador had more technical barriers than expected (more than in surrounding countries, taking the difference in independent variable values into account), while Norway, Russia and the Philippines introduced fewer protectionist measures than predicted after 999 LISA permutations.
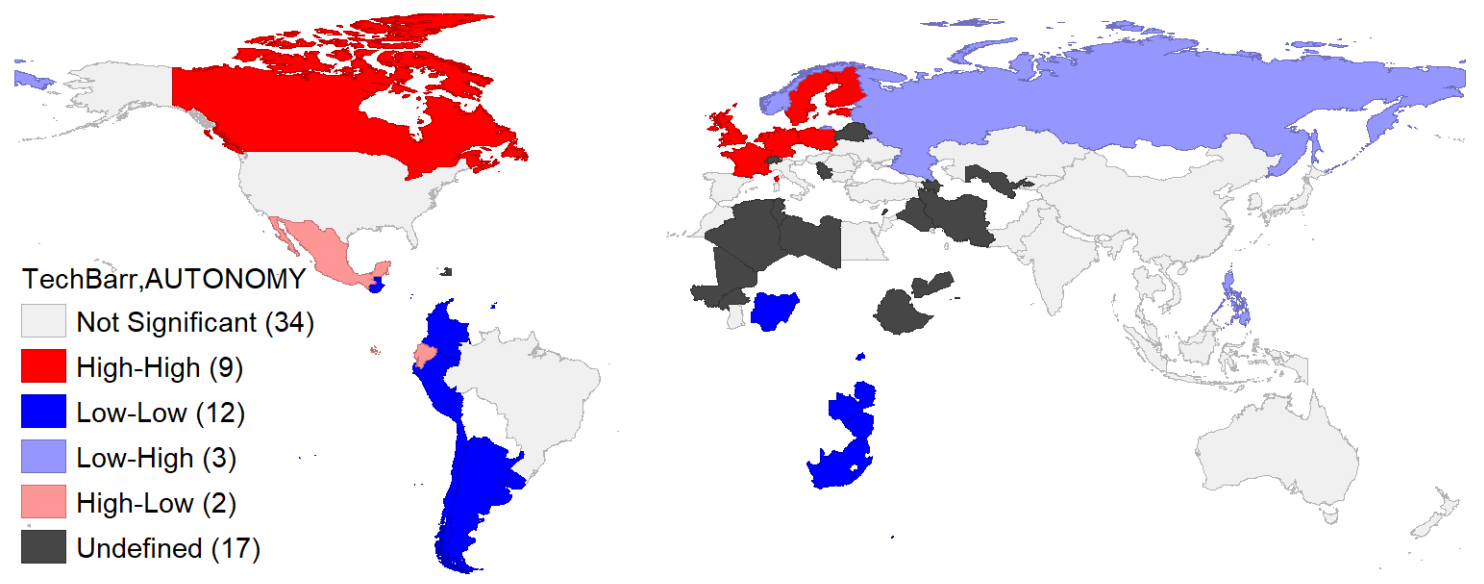

Figure 5. Local indicators of spatial association (LISA) between autonomy index and the number of technical trade barriers

\section{Discussion}

The abovementioned willingness to establish technical barriers to goods coming from states with low GDP PPP per capita, low competitiveness scores and high fragility values and surrounded by countries with a considerable share of non-conformist citizens can be attributed to defensive policy reactions as risk aversion strategies to deal with transborder trade flows. The underpinning assumption behind this policy 
preference is the unfavourable perception of contiguous trade partners and the belief that opening trade channels to these countries would be dangerous. This belief could be based on how the negative opinions of political actors regarding their international surroundings manifest themselves: the stigmatization of at least some neighbouring societies. In turn, these evaluations could be based on cautious risk assessments related to at least one type of threat originating from other countries: the propensity of their workers to deviate from standards of quality manufacturing. These moods and the resulting intentions may be seen as dangerous by political actors across the border from these workers, because if manufacturers prefer not to stick to the rules, then the resulting products could end up being unreliable or detrimental to consumer health.

The observed moderation effect could also be explained within the same theoretical framework. Fragile states with a low GDP PPP per capita, as well as poor Competitiveness Index and Globalization Index scores, were found to introduce more technical barriers to international trade than other states in the same surrounding (in the face of the non-conformist attitudes of citizens in neighbouring countries). Probably, they expected potential damage to the wellbeing of their inhabitants' well-being to be greater than in the case of more 'successful' states.

Specifically, highly developed countries can cope with the risks of keeping borders with 'unpredictable' societies (with disobedient and potentially rule-violating citizens) open. Indeed, many well-off citizens can afford to choose goods on the basis of quality, and not price (supposing that products that are known to be of poor quality are cheaper than others, in which case those people would buy higher-quality goods that are more expensive).

On the contrary, resource limitations in 'vulnerable' states result in greater caution (i.e., lower risktolerance and greater sensitivity to cross-border threats) with regard to international flows of potentially unreliable or unhealthy products. Following the same logic of choosing between cheap, low-quality products and expensive, high-quality products, many customers who are not particularly well-off can only afford the former. Consequently, if the government aims to protect people's health and way of life, the authorities make it harder to buy poor-quality products by introducing additional import barriers.

The LISA results can be explained by the concerns of citizens in Mexico and Ecuador about the quality of imported goods. Mexico may have introduced more technical standards, relatively speaking, than most other countries in its region (and among societies with comparable levels of social deviance), because the country state is more fragile than they are. Meanwhile, Ecuador may have introduced more technical standards due to the country's lower economic development and competitiveness.

In contrast, other outliers introduced relatively less technical trade barriers than countries in their regions. It appears that these states can afford being to be less anxious about their trade openness: Norway is more competitive than its neighbours (consequently, Norwegian people are more confident that they will have enough money to purchase more expensive, high-quality products). Russia is more economically developed and less fragile than most post-Soviet states (a fact that also increases its financial stability). As for the Philippines, its decision-makers may be willing to place more restrictions on trade flows, but its economy does not appear to be sufficiently diversified to reject certain types of imported goods. In the absence of domestic industries, this will lead to a deficit on their markets.

\section{CONCLUSION}

The bivariate spatial autocorrelation analysis was carried out using 2005-2019 indicators for 77 countries distributed across all continents and overlaid onto a world map that accurately reflects contiguity relations between these nation states. Non-tariff trade barriers (namely, technical standards) among states with low GDP PPP per capita, low competitiveness scores and high fragility values and surrounded by countries 
with a considerable share of non-conformist citizens were found to be stronger than in the other countries. This willingness to apply technical barriers to goods coming from these countries was attributed to defensive policy reactions as risk aversion strategies to deal with transborder trade flows.

A moderation effect was observed: fragile states with low GDP PPP per capita, as well as poor Competitiveness Index and Globalization Index scores, were found to introduce more technical barriers to international trade than other states in the same surrounding (in the face of the non-conformist attitudes of citizens in neighbouring countries). LISA calculations revealed contrasting reactions to neighbouring societies by states in the same regions. Several countries stand out in terms of the number of technical barriers they have introduced compared to the level of non-conformity of neighbouring societies: Mexico and Ecuador introduced more non-tariff barriers than expected, whereas Norway, Russia and the Philippines established fewer protectionist measures.

\section{ACKNOWLEDGEMENT}

This research was funded by the Institute for International Studies at MGIMO University (Moscow State Institute of International Relations), Project Number 1921-01-09 "Geopolitical Atlas of the Modern World: Cartograms Modeling, Multidimensional Scaling and Determination of Local Indicators of Spatial Autocorrelation in World Politics."

\section{REFERENCES}

Abdelal, R., Blyth, M., \& Parsons, C. (2010). Introduction: Constructing the International Economy. In: R. Abdelal, M. Blyth, C. Parsons (eds.), Constructing the International Economy (pp. 1-20). Ithaca: Cornell University Press.

Anderson, W. (1995). Excremental Colonialism: Public Health and the Poetics of Pollution. Critical Inquiry, 21 (3), 640669.

Anderson, K., \& Smith, S. (2002). Emotional Geographies. Transactions of the Institute of British Geographers, 26 (1), 7-10. Anselin, L. (1995). Local Indicators of Spatial Association - LISA. Geographical Analysis, 27 (2), 93-115.

Anselin, L. (2018). Distance-Band Spatial Weights. Retrieved February 14, 2020, from https://geodacenter.github.io/workbook/4b_dist_weights/lab4b.html\#k-nearest-neighbor-weights.

Anselin, L. (2019). A Local Indicator of Multivariate Spatial Association, Extending Geary's C. Geographical Analysis, 51 (2), 133-150.

Auer, R., Fischer, A. (2010). The Effect of Low-Wage Import Competition on U.S. Inflationary Pressure. Journal of Monetary Economics, 4, 491-503.

Balsiger, P. (2010). Making Political Consumers: The Tactical Action. Repertoire of a Campaign for Clean Clothes. Social Movement Studies, 9 (3), 311-329.

Beck, U. (2009). Critical Theory of World Risk Society: A Cosmopolitan Vision. Constellations, 16 (1), 3-22.

Beckert, J. (2020). Markets from Meaning: Quality Uncertainty and the Intersubjective Construction of Value. Cambridge Journal of Economics, 44 (2), 285-301.

Bleiker, R., Leet, M. (2006). From the Sublime to the Subliminal: Fear, Awe and Wonder in International Politics. Millennium: Journal of International Studies, 34 (3), 713-737.

Boltanski, L., Thévenot, L. (1991). De la justification: les économies de la grandeur. Paris: Gallimard.

Bondi, L., Davidson, J., Smith, M. (2005). Introduction: Geography's "Emotional Turn". In: J. Davidson, L. Bondi, M. Smith (eds.). Emotional Geographies (pp. 1-16). Ashgate: Aldershot.

Bourdieu, P. (1984). Distinction: A Social Critique of the Judgement of Taste. Cambridge: Harvard University Press.

Bourdieu, P., Thompson, J. (1991). Language and Symbolic Power. Cambridge: Harvard University Press.

Buzan, B., Wrver, O. (2003). Regions and Powers: The Structure of International Security. Cambridge: Cambridge University Press.

Calleo, D., \& Rowland B. (1973). America and the World Political Economy. Bloomington: Indiana University Press.

Callon, M., Méadel, C., \& Rabeharisoa, V. (2002). The Economy of Qualities. Economy and Society, 31 (2), $194-217$. 
Chen, Y. (2012). On the Four Types of Weight Functions for Spatial Contiguity Matrix. Letters in Spatial and Resource Sciences, 5, 65-72.

Cheyne, I. (2007). Gateways to the Precautionary Principle in WTO Law. Journal of Environmental Law, 19 (2), $155-172$. Cliff, A., \& Keith, O. (1973). Spatial Autocorrelation. London: Pion.

Country Dashboard (2018). Retrieved October 1, 2019, from https://fragilestatesindex.org/country-data/.

Crewe, L. (2011). Geographies of Retailing and Consumption: The Shopping List Compendium. In: A. Leyshon, R. Lee, L. McDowell, P. Sunley (eds.). The Sage Handbook of Economic Geography (pp. 304-319). Los Angeles and London: Sage.

Culbertson, J. (1986). A Realist View of International Trade and National Trade Policy. New York University Journal of International Law and Politics, 18 (4), 1119-1132.

De Castro, M., Burton, S. (2006). Controlling the False Discovery Rate: An Application to Account for Multiple and Dependent Tests in Local Statistics of Spatial Association. Geographical Analysis, 38 (2), 180-208.

De Goede, M. (2006). Introduction: International Political Economy and the Promises of Poststructuralism. In: M. De Goede (ed.). International Political Economy and Poststructural Politics (pp. 1-20). London: Palgrave Macmillan UK.

Dasarathy, B. (1991). Nearest Neighbor (NN) Norms: NN Pattern Classification Techniques. IEEE Computer Society Press, Los Alamitos.

Deutsch, K. (1988). The Analysis of International Relations. New Jersey: Prentice Hall.

Dosman, D., Adamowicz, W. and Hrudey, S. (2001). Socioeconomic determinants of health- and food safety-related risk perceptions. Risk Analysis, 21 (2), 307-317.

Douglas, M. (1966). Purity and Danger: An Analysis of Concepts of Pollution and Taboo. New York: Praeger Publishers.

Douglas, M. (1992). Risk and Blame: Essays in Cultural Theory. London: Routledge.

Easton, D. (1965). A Systems Analysis of Political Life. New York: Wiley.

Epps, T. (2008). Reconciling Public Opinion and WTO Rules under the SPS Agreement. World Trade Review, 7 (2), 359-392.

Fajgelbaum, P., Khandelwal, A. (2016). Measuring the Unequal Gains from Trade. The Quarterly Journal of Economics, 131 (3), 1113-1180.

Flanquart, H. (2012). An Unwelcome User? Or How to Negotiate the Use of a Risky Space. Journal of Risk Research, 15 (10), 1261-1279.

Friedman, M. (2010). Consumer Boycotts: A Conceptual Framework and Research Agenda. Journal of Social Issues, 47 (1), 149-168.

Global Competitiveness Index 2017-2018 (2019). Retrieved October 1, 2019, from http:// reports.weforum.org/global-competitiveness-index-2017-2018/competitiveness-rankings/\#series=GCI.

Goffman, E. (1963). Stigma: Notes on the Management of Spoiled Identity. New York: Simon and Schuster.

Goldstein, B., Carruth, R. (2004). The Precautionary Principle and Risk Assessment in World Trade Organization Decisions: A Possible Role for Risk Perception. Risk Analysis, 24 (2), 491-499.

Granovetter, M. (1985). Economic Action and Social Structure: The Problem of Embeddedness. The American Journal of Sociology, 91 (3), 481-510.

Gudeman, S. (1986). Economics as Culture - Models and Metaphors of Livelihood. London: Routledge and Kegan Paul.

Guisinger, A. (2017). American Opinion on Trade: Preferences Without Politics. New York: Oxford University Press.

Guiso, L., Sapienza, P., Zingales, L. (2003). People's Opium? Religion and Economic Attitudes. Journal of Monetary Economics, 50 (1), 225-282.

Hall, R. (2006). Human Nature as Behavior and Action in Economics and International Relations Theory. Journal of International Relations and Development, 9 (3), 269-287.

Hays, J., Ehrlich, S., \& Peinhardt, C. (2005). Government Spending and Public Support for Trade in the OECD: An Empirical Test of the Embedded Liberalism Thesis. International Organization, 59 (2), 473-494.

Hill, C., \& Wallace, W. (1996). Introduction: actors and actions. In C. Hill (ed.), The Actors in Europe's Foreign Policy (pp. 13-38). London: Routledge. 
Hobson, J., \& Seabrooke, L. (2007). Everyday Politics of the World Economy. In: J. Hobson, L. Seabrooke (eds.), Everyday Politics of the World Economy (pp. 1-24). Cambridge: Cambridge University Press.

Holsti, O. (2004). Public Opinion and American Foreign Policy, revised edition. Ann Arbor: University of Michigan Press.

Huei-Chih, N. (2007). Can Article 5.7 of the WTO SPS Agreement Be a Model for the Precautionary Principle? Scripted, 4 (4), 367-382.

I-TIP Goods (2020). Retrieved October 1, 2019, from http://itip.wto.org/goods/Forms/GraphView.aspx?period=y\&scale=lg.

Inglehart, R., Haerpfer, C., Moreno, A., Welzel, C., Kizilova, K., Diez-Medrano, J., Lagos, M., Norris, P., Ponarin, E. and Puranen, B. et al. (eds.) (2014). World Values Survey: All Rounds - Country-Pooled Datafile Version. Retrieved October 1, 2019, from http://www.worldvaluessurvey.org/WVSDocumentationWVL.jsp.

Khunwishit, S., McEntire, D. (2012). Testing Social Vulnerability Theory: A Quantitative Study of Hurricane Katrina's Perceived Impact on Residents living in FEMA Designated Disaster Areas. Journal of Homeland Security and Emergency Management, 9 (1), 1-16.

KOF Globalization Index (2018). Retrieved October 1, 2019, from https://kof.ethz.ch/en/forecasts-andindicators/indicators/kof-globalisation-index.html.

Krasner, S. (1999). Globalization and Sovereignty. In D. Smith (ed.), States and Sovereignty in the Global Economy (pp. 3452). London: Routledge.

Kristeva, J. (1982). Powers of Horror: An Essay on Abjection. New York: Columbia University Press.

Lorot, P. (1999). Introduction à la géoéconomie. Paris: Economica.

Luckmann, T., Berger, P. (1966). The Social Construction of Reality: a Treatise in the Sociology of Knowledge. New York: Anchor.

Luhmann, N. (1995). Social Systems. Stanford: Stanford University Press.

Luttwak, E. (1990). From Geopolitics to Geo-Economics: Logic of Conflict, Grammar of Commerce. The National Interest, 20, 17-23.

Mansfield, E., Busch, M. (1995). The Political Economy of Non-Tariff Barriers: A Cross-National Analysis. International Organization, 49 (4), 723 - 749.

Mansfield, E., Mutz, D. (2009). Support for Free Trade: Self-Interest, Sociotropic Politics, and Out-Group Anxiety. International Organization, 63 (3), 425-457.

Mayda, A., Rodrik, D. (2005). Why Are Some People (and Countries) More Protectionist Than Others? European Economic Review, 49 (6), 1393-1430.

Mearsheimer, J. (2001). The Tragedy of Great Power Politics. New York: W.W. Norton.

Melgar, N., Milgram-Baleix, J., Rossi, M. (2013), Explaining Protectionism Support: The Role of Economic Factors. International Scholarly Research Notices, 1, 1-14.

Merton, R. (1968). Social Theory and Social Structure (3rd edition). Glencoe: Free Press.

Meunier, S. (2005). Trading Voices: The European Union in International Commercial Negotiations. Princeton: Princeton University Press.

Moore, S. (2009). The Excess of Modernity: Garbage Politics in Oaxaca, Mexico. The Professional Geographer, 61, 426437.

Moravcsik, A. (1997). Taking Preferences Seriously: A Liberal Theory of International Politics. International Organization, 51 (4), $513-553$.

Okunev, I., Barinov, S., Belikov, A., Vinogradov, V., Bibina, E., Domanov, A., Zhirnova, L., Zakharova, E., Ostapenko, G., Polyakova, Y., Tislenko, M., Shmatkova, L. (2020, in Russian). Atlas mezhdunarodnykh otnoshenij: Prostranstvennyj analiz indikatorov mirovogo razvitija [Atlas of International Relations: Spatial Analysis of World Development Indicators]. Moscow: MGIMO University.

Onuf, N. (1997). A Constructivist Manifesto. In: K. Burch, R. Denemark (eds.), Constituting International Political Economy. (pp. 7-20). Boulder: Lynne Rienner Publishers.

Perdikis, N., Shelburne, W., Hobbs, J. (2001). Reforming the WTO to Defuse Potential Trade Conflicts in Genetically Modified Goods. The World Economy, 24 (3), 379-398.

Poortinga, W., Cox, P., \& Pidgeon, N. (2008). The Perceived Health Risks of Indoor Radon Gas and Overhead Powerlines: A Comparative Multilevel Approach. Risk Analysis, 28 (1), 235-248. 
Post, D. (2006). The Precautionary Principle and Risk Assessment in International Food Safety: How the World Trade Organization influences standards. Risk. Analysis, 26 (5), 1259-1273.

Prattis, J. (1982). Synthesis, or a New Problematic in Economic Anthropology. Theory and Society, 11, $205-228$.

Rathbun, B. (2011). Trust in International Cooperation: International Security Institutions, Domestic Politics and American Multilateralism. Cambridge: Cambridge University Press.

Rickard, S. (2012). A Non-Tariff Protectionist Bias in Majoritarian Politics: Government Subsidies and Electoral Institutions. International Studies Quarterly, 56 (4), 777-785.

Riezman, R., Whalley, J. and Zhang, S. (2011). Distance Measures Between Free Trade and Autarky for the World Economy. Economic Modelling, 28 (4), 2000-2012.

Rinkinen, J., Shove, E., Marsden, G. (2020). Conceptualising Demand: A Distinctive Approach to Consumption and Practice. New York: Routledge.

Scheve, K., Slaughter, M. (2001). What Determines Individual Trade Policy Preferences? Journal of International Economics, 54 (2), 267-292.

Scholz, R., Blumer, Y. and Brand, F. (2012). Risk, Vulnerability, Robustness and Resilience from a Decision-Theoretic Perspective. Journal of Risk Research, 15 (3), 313-330.

Shove E. (2003). Comfort, Cleanliness and Convenience: The Social Organization of Normality. Oxford: Berg Publishers.

Sparke, M. (2007). Geopolitical Fears, Geoeconomic Hopes, and the Responsibilities of Geography. Annals of the Association of American Geographers, 97 (2), 338-349.

Storper, M., Salais, R. (1997). Worlds of Production: The Action Frameworks of the Economy. Cambridge: Harvard University Press.

Tyler, I. (2013). Revolting Subjects: Social Abjection and Resistance in Neoliberal Britain. London: Zed Books.

Valentine, G. (2008). Living with Difference: Reflections on Geographies of Encounters. Progress in Human Geography, 32 (3), 323-337.

Wacquant, L. (2010). Crafting the Neoliberal State: Workfare, Prisonfare, and Social Insecurity. Sociological Forum, 25, (2), 197-220.

Wacquant, L., Slater, T. and Pereira, V. (2014). Territorial Stigmatization in Action. Environment and Planning A, 46, (6), $1270-1280$.

Waltz, K. (2008). Realism and International Politics. New York: Routledge.

Welzel, C. (2013). Freedom Rising. Human Empowerment and the Quest for Emancipation. Cambridge: Cambridge University Press.

Wendt, A. (1992). Anarchy is What States Make of It: The Social Construction of Power Politics. International Organization, 46, (2), 391-425.

World Borders Dataset (2019). Retrieved September 1, 2019, from http://thematicmapping.org/downloads/TM_WORLD_BORDERS-0.3.zip.

World Economic Outlook Database (2019). Retrieved October 1, 2019, from https://www.imf.org/external/pubs/ft/weo/2019/01/weodata/weorept.aspx.

Wullweber, J. (2018). Poststructural Research in International Political Economy. In: Sandal N. (ed.). Oxford Research Encyclopedia of International Studies (pp. 103-117). Oxford: Oxford University Press. 


\section{APPENDIX}
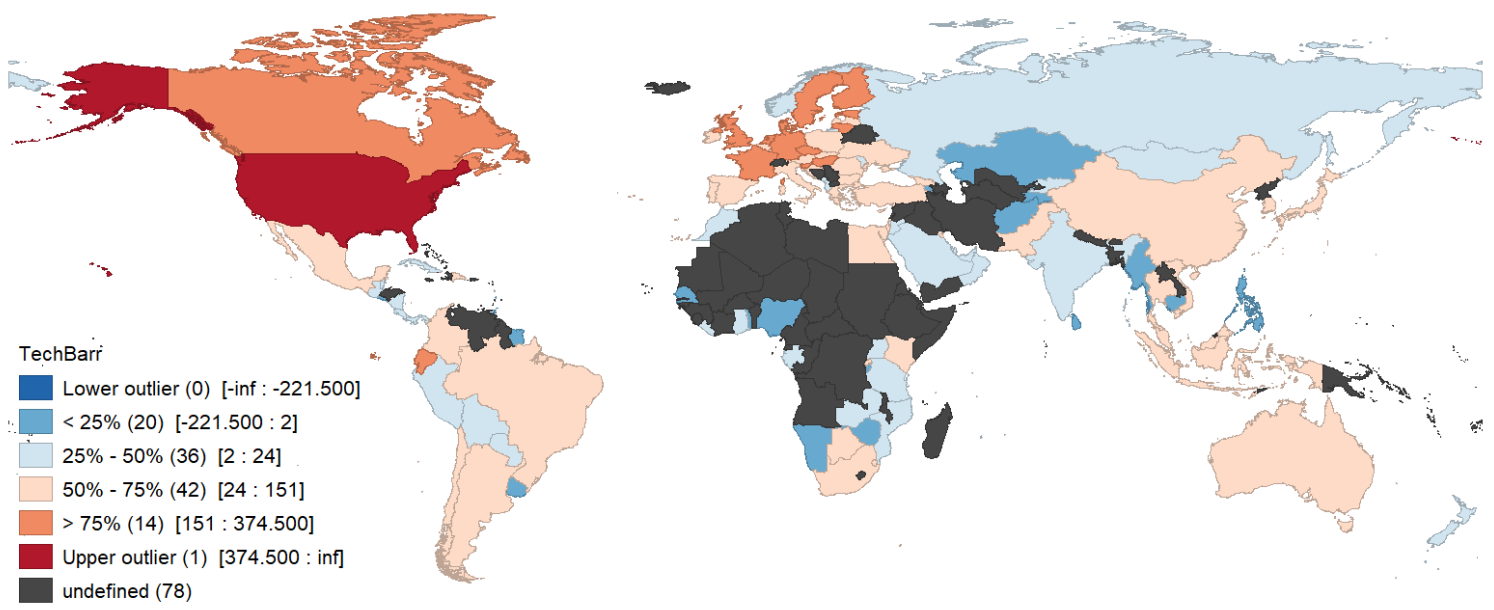

Figure 6. Box plot of dependent variable values: number of technical non-tariff custom barriers Source: WTO (I-TIP Goods, 2020)
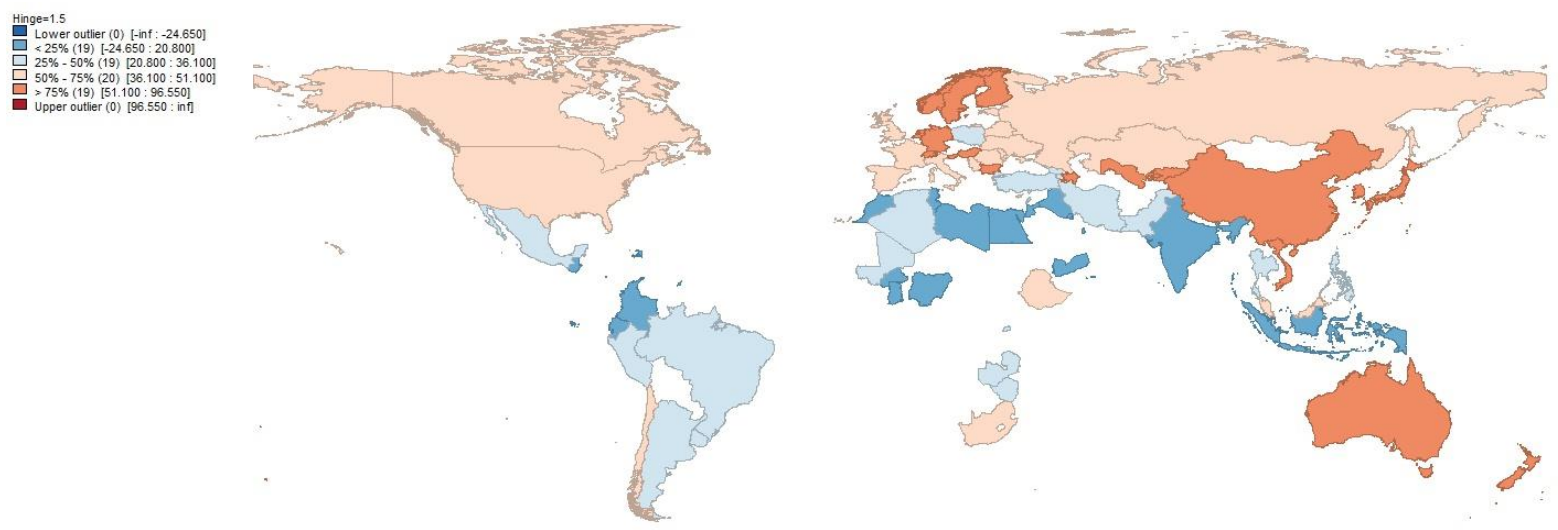

Figure 7. Box Plot of Independent Variable Values: Autonomy Index (Low Conformity Corresponds to Decreased Values)

Source: World Values Survey (Inglehart et al., 2014)
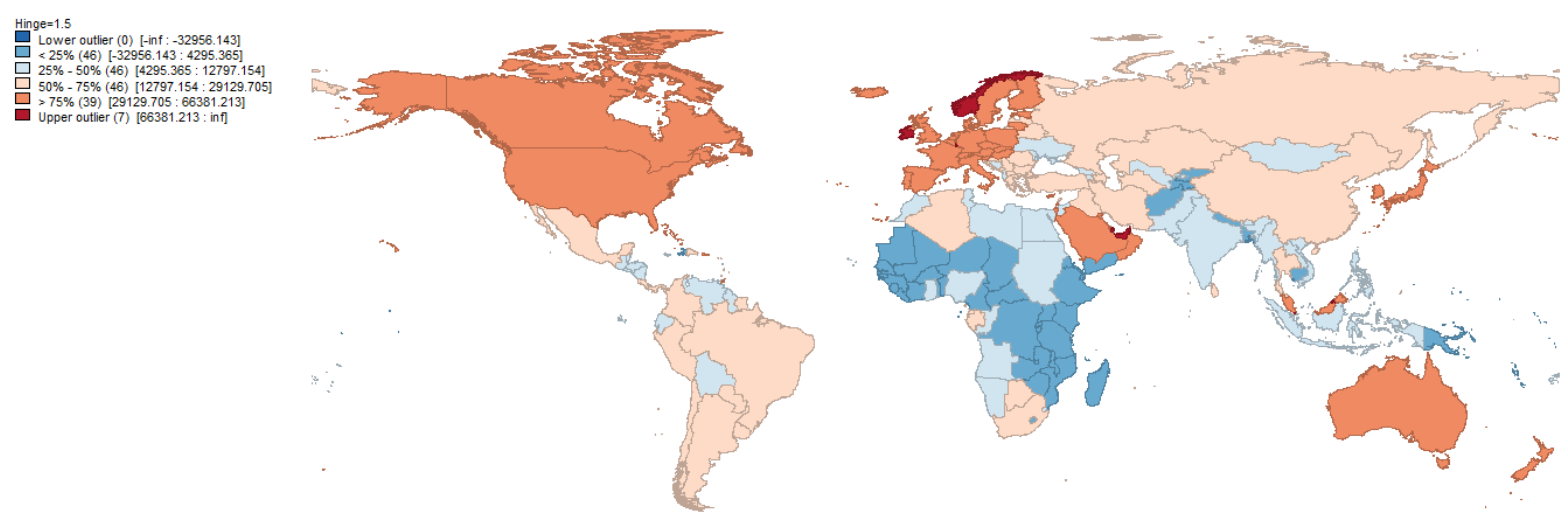

Figure 8. Box Plot of Moderating Variable Values: GDP PPP Per Capita in 2018, int. dollars Source: IMF (World Economic Outlook Database, 2019) 

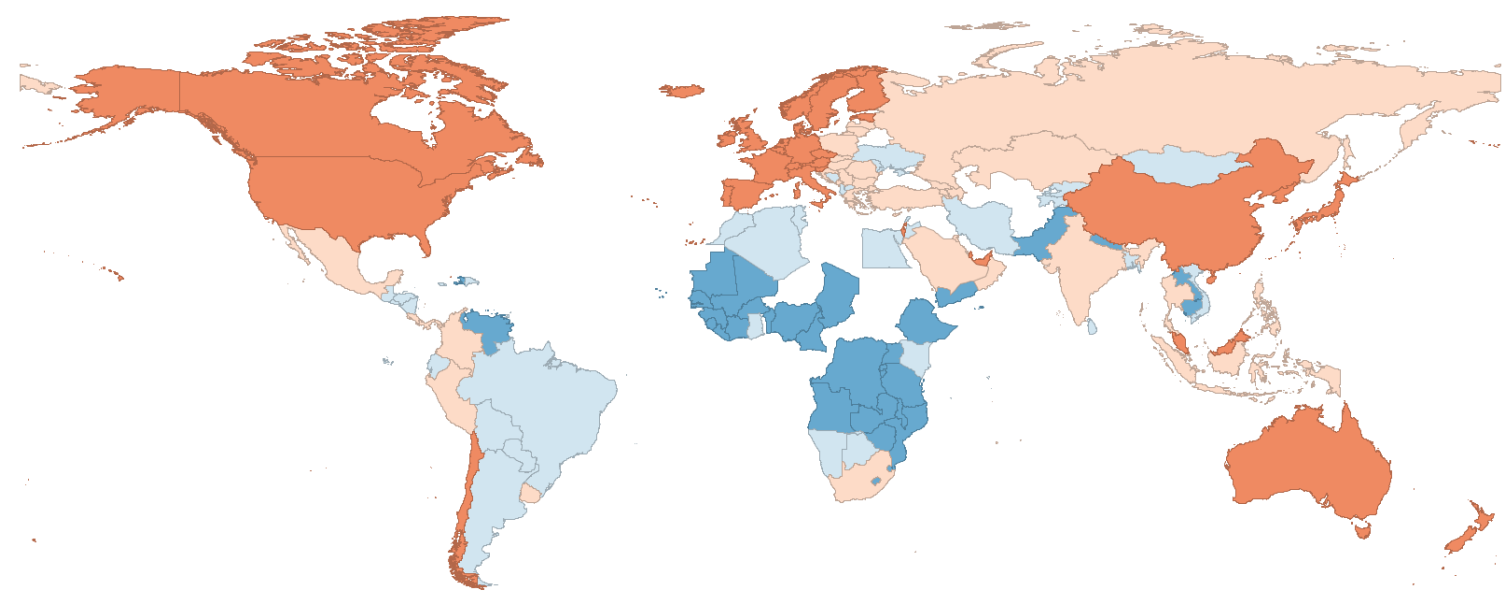

Figure 9. Box Plot of Moderating Variable Values: Competitiveness Index for 2017-2018 Source: World Economic Forum (Global Competitiveness Index, 2019)
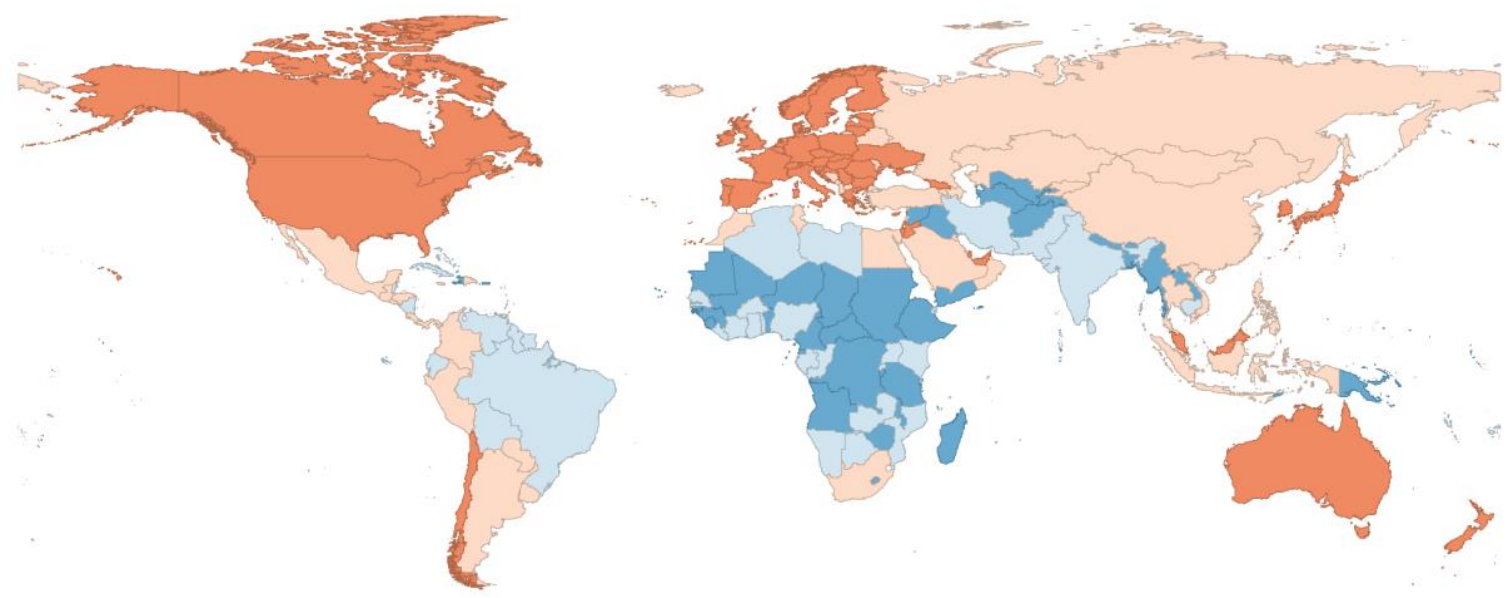

Figure 10. Box plot of moderating variable values: KOF globalization index in 2018 Source: The Swiss Economic Institute (KOF Globalization Index, 2018) 

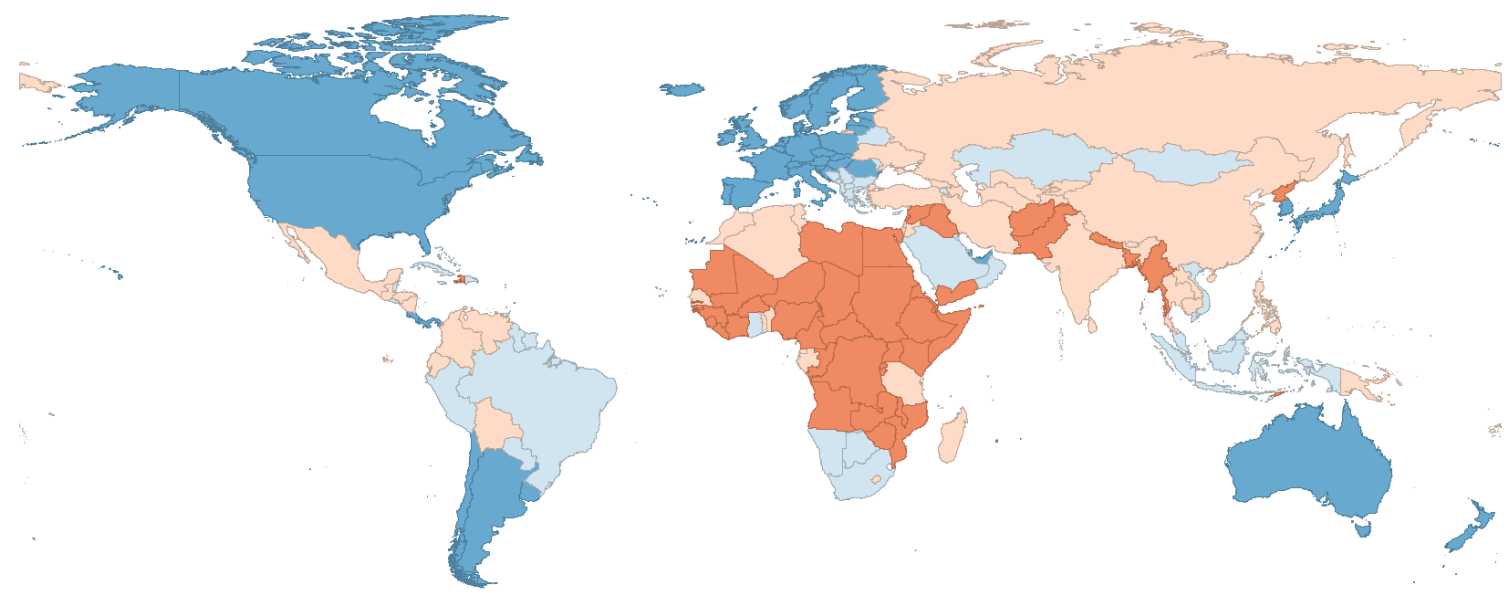

Figure 11. Box plot of moderating variable values: Fragile states index in 2017 Source: Fund for Peace (Country Dashboard, 2018) 